\title{
Ikke-tekniske ferdigheter må integreres i \\ utdanningen av \\ sykepleiere
}

Særlig i situasjoner med akutt kritisk syke pasienter vil ikke-tekniske ferdigheter bidra til å forebygge menneskelig svikt og dermed redusere antallet pasientskader.

\section{Fiona M. Flynn}

Universitetslektor

Fakultet for helse- og sosialvitenskap, Universitetet i Sørøst-Norge, Campus Vestfold

\section{Kjersti Sandaker}

Anestesisykepleier

Anestesiavdelingen, Sykehuset Vestfold

\section{Siri Tønnessen}

Professor

Universitetet i Sørøst-Norge

\section{Berit Taraldsen Valeberg}

\section{Professor}

Oslomet - storbyuniversitetet og Universitetet i Sørøst-Norge 
Hvert år påføres pasienter skader i helsetjenesten. Gode ikke-tekniske ferdigheter hos sykepleiere kan forebygge menneskelig svikt og styrke pasientsikkerheten. Denne artikkelen beskriver hvordan utvikling og vurdering av ikke-tekniske ferdigheter i sykepleierutdanningen kan sikre at studenter oppnår den nødvendige kompetansen for å møte helsetjenestens krav til kvalitet og pasientsikkerhet.

De to siste tiårene har det vært mye internasjonal oppmerksomhet på pasientsikkerhet og en bred erkjennelse av at menneskelig svikt i helsetjenesten kan påføre pasienter un $\varnothing$ dvendige skader (1). Utilsiktede eller uheldige hendelser som følge av menneskelig svikt kan defineres som en handling eller omstendighet som ikke skulle ha forekommet (2).

Årsakene er ofte sammensatte, men flere studier viser at gode ikke-tekniske ferdigheter hos helsepersonell bidrar til å forebygge menneskelig svikt og dermed til å redusere antallet pasientskader (3). Særlig i situasjoner med akutt kritisk syke pasienter hvor sykepleiere arbeider tett sammen med andre profesjoner, vil gode ikke-tekniske ferdigheter ha stor betydning $(4,5)$.

Til tross for $\varnothing \mathrm{kt}$ bevissthet om betydningen av disse ferdighetene i sykepleierutdanningene både i Norge og internasjonalt er utvikling og vurdering av ikketekniske ferdigheter fremdeles ikke systematisk integrert i utdanningen (6). Denne fagartikkelen baserer seg på forskning og erfaringer fra anestesisykepleierutdanningen ved Universitetet i Sørøst-Norge, men temaet er også relevant for andre sykepleiergrupper.

\section{Hva er ikke-tekniske ferdigheter?}


Ikke-tekniske ferdigheter er kognitive, sosiale og mellommenneskelige ferdigheter som sammen med tekniske ferdigheter utgjør individets evne til å bidra til en effektiv og sikker oppgavehåndtering (7). På andre områder av samfunnet hvor menneskelig svikt kan ha katastrofale følger, for eksempel innen luftfart, har utvikling av ikke-tekniske ferdigheter lenge vært i fokus. Gode ikke-tekniske ferdigheter er like viktig i alle typer pasientarbeid, fra akutte situasjoner til daglig rutinearbeid (8).

Flin og medarbeidere (7) har identifisert sju ulike ikketekniske ferdigheter som påvirker handlingsvalg i arbeidssituasjoner med høy risiko: situasjonsbevissthet, beslutningstaking, kommunikasjon, teamarbeid, ledelse, mestring av stress og mestring av mental utmattelse. For sykepleiere er kognitive prosesser som situasjonsbevissthet og beslutningstaking, sammen med mellommenneskelige ferdigheter som oppgaveløsning, kommunikasjon og teamarbeid, beskrevet som nøkkelferdigheter $(9,10)$.

\section{Situasjonsbevissthet}

Situasjonsbevissthet er evnen til å fange opp viktig informasjon og endringer fra omgivelsene, forstå betydning av denne informasjonen, og deretter å forutse hvordan situasjonen kan komme til å utvikle seg videre (11). Dette krever årvåkenhet, kunnskap og erfaring.

\section{«En sykepleierstudent vil ha langt færre erfaringer lagret.»}

Sykepleiere samler inn informasjon om pasientens tilstand og setter den sammen ved hjelp av arbeidsminnet, som er den delen av hukommelsen hvor informasjon lagres og bearbeides i korte perioder. I arbeidsminnet sammenliknes informasjonen med liknende erfaringer lagret $\mathrm{i}$ langtidshukommelsen for å forstå det som skjer. 
Sammenliknet med en erfaren sykepleier vil en sykepleierstudent ha langt færre erfaringer lagret, og vil dermed ikke ha de samme forutsetningene for å forstå endringer i pasientens tilstand. Dette kan redusere den uerfarnes evne til å forutse konsekvenser og forebygge uønskede hendelser ved å ta hensiktsmessige beslutninger (11).

\section{Beslutningstaking}

Beslutningstaking handler om sykepleieres evne til å identifisere et problem og vurdere risikofaktorer og tiden som er tilgjengelig før en relevant respons eller handling velges. Dersom risikoen vurderes som lav, vil sykepleieren ha tid til å vurdere flere alternativer og være kreativ eller analytisk ved valg av den optimale løsningen.

I akutte situasjoner, som ved hjertestans, er tiden begrenset, og beslutninger må fattes automatisk for raskt å få kontroll over situasjonen (7). Til slutt er revurdering av beslutninger viktig for å sikre at responsen var riktig.

\section{Oppgaveløsning}

Oppgaveløsning er en ferdighet med både kognitive og mellommenneskelige komponenter. Oppgaveløsning vil si å planlegge, prioritere og koordinere tilgjengelige ressurser på en mest mulig hensiktsmessig måte (7).

I akutte situasjoner må sykepleiere kunne håndtere flere oppgaver samtidig og prioritere i riktig rekkefølge (7). God oppgaveløsning og alltid å ha en plan B bidrar til bedre teamarbeid (12).

\section{Teamarbeid}

Mellommenneskelige ferdigheter som kommunikasjon, samarbeid og koordinering av aktiviteter står sentralt i teamarbeid (7). Kommunikasjonen bør være presis, tydelig og forståelig. Manglende eller utydelig kommunikasjon vil påvirke andre teammedlemmers atferd og hvordan oppgaver løses i teamet. 
Når teamet består av ulike profesjonsut øvere med egendefinerte oppgaver, vil utfordringen for den enkelte være å kunne «heve blikket» og se de andre teammedlemmenes kompetanse og behov, og å bidra mot et felles mål. Det krever blant annet en klar og definert forståelse av hva ens egen rolle innebærer, hvilken kompetanse den bygger på, og hvilke begrensninger den har. Også manglende kjennskap til andre teammedlemmers rolle og kompetanse kan påvirke hvor godt man fungerer i et team (5).

\section{Foretak og utdanninger bør få felles rammeverk}

Formativ vurdering har som mål å fremme læring og personlig utvikling. Foreløpig finnes det fă validerte verkt $\varnothing y$ for formativ vurdering av sykepleieres ikketekniske ferdigheter, både nasjonalt og internasjonalt $(6,13)$. Det eneste verktøyet som er reliabilitetstestet for bruk i klinisk praksis i Norge, er Nurse Anaesthetists' Non-Technical Skills - Norway (NANTS-no) $(9,14)$.

Hensikten med NANTS-no er å etablere et felles rammeverk for ikke-tekniske ferdigheter for utdanningsinstitusjoner og helseforetak. Verkt øyet bygger på en tilpasning av Anaesthetists' NonTechnical Skills (ANTS), som ble utviklet for anestesileger i Storbritannia (15).

Det har nylig også kommet et liknende verktøy for operasjonssykepleiere i Norge, Scrub Practitioners' List of Intraoperative Non-Technical Skills (SPLINTSno) (10), men den norske versjonen av dette verktøyet er foreløpig ikke reliabilitetstestet.

NANTS-no omfatter fire kategorier av ikke-tekniske ferdigheter med til sammen femten elementer (se tabell 1). Ved hvert element gis det konkrete eksempler på hensiktsmessig og uhensiktsmessig atferd som er relevant for konteksten verktøyet skal brukes i. 
Verktøyet har en vurderingsskala fra 1 til 5, hvor 1 er atferd som setter pasientens sikkerhet i fare, mens $5 \mathrm{er}$ atferd som viser høy faglig standard. Vurderingen av studentenes kompetanse er basert på det forventede nivået for en ferdigutdannet anestesisykepleier (16). Vurderingsskalaen kan dermed vise progresjonen til studentene gjennom hele utdanningsforl $\varnothing$ pet.

Tabell 1. Kategorier og elementer i NANTS-no

\begin{tabular}{|c|c|}
\hline Kategorier & Elementer \\
\hline Situasjonsbevissthet & $\begin{array}{l}\text { - innhente informasjon } \\
\text { - identifisere og forstå } \\
\text { - forutse og være i forkant }\end{array}$ \\
\hline Beslutningstaking & $\begin{array}{l}\text { - identifisere handlingsalternativer } \\
\text { - vurdere risikofaktorer og velge handlingsalternativ } \\
\text { - revurdere }\end{array}$ \\
\hline Oppgaveløsning & $\begin{array}{l}\text { - planlegge og forberede } \\
\text { - prioritere } \\
\text { - identifisere og anvende ressurser } \\
\text { - overholde standarder og kvalitet }\end{array}$ \\
\hline Teamarbeid & $\begin{array}{l}\text { - utveksle informasjon } \\
\text { - vurdere roller og kompetanser } \\
\text { - koordinere aktiviteter } \\
\text { - vise autoritet og gjennomslagskraft } \\
\text { - støtte andre teammedlemmer }\end{array}$ \\
\hline
\end{tabular}

\section{NANTS-no fremmer kritisk refleksjon}

Klinisk veiledning knytter sammen teori og praksis og er en viktig del av sykepleierutdanningen på alle nivåer (17). Veiledning tilrettelegger for profesjonell og personlig utvikling gjennom kritisk refleksjon, samtidig som studentene får råd og støtte $(17,18)$.

Forholdet mellom student og veileder er viktig for å skape rom for læring og styrke den faglige identiteten til studenten. Studenter og veiledere må søke å etablere seg som likeverdige partnere i dette forholdet, slik at dialog og kritisk refleksjon kan føre til utvikling av kunnskap $(17,19)$. 
Hensikten med å bruke NANTS-no i veiledning er å fremme kritisk refleksjon hos studentene og å bevisstgjøre dem om deres atferd og progresjon. NANTS-no kan være et utgangspunkt for refleksjon rundt en enkelt pasientsituasjon, jevnlige samtaler om faglig utvikling eller vurdering av hele praksisperioder. De konkrete eksemplene på hensiktsmessig og ikke hensiktsmessig atferd belyser styrker og svakheter i sykepleieutøvelsen og kan brukes for å synliggjøre hva studentene mestrer, og hva de må jobbe videre med.

\section{«Verktøyet gjør det lettere å sette ord på utfordringer.»}

I starten kan NANTS-no virke omfattende, og det kan derfor være hensiktsmessig å velge ut én kategori eller noen elementer som fokusområde istedenfor å bruke hele verktøyet hver gang.

Verktøyet gir en tydelig struktur for dialog om studentens utvikling gjennom studiet. I tillegg kan slike verkt øy gjøre det enklere for veiledere og lærere å gi konkrete tilbakemeldinger om forbedringsområder fordi slike tilbakemeldinger ikke oppfattes som kritikk av studentens personlighet (20).

Dette er særlig nyttig når det gjelder egnethet, fordi verktøyet gjør det lettere å sette ord på utfordringer og å tydeliggjøre hvilke ferdigheter som kreves av en anestesisykepleier. Vi er i gang med å unders $\emptyset$ ke nærmere studenters og veilederes erfaringer med bruk av verktøyet i klinisk praksis.

NANTS-no kan også brukes i simuleringstrening for å rette fokus på kommunikasjon, rollefordeling og samhandling i team, og det gir en tydelig struktur på tilbakemeldingene under debrifingen (9). 


\section{Observasjon av ikke-tekniske ferdigheter bør læres}

Det anbefales et todagers treningskurs for å lære observasjon av ikke-tekniske ferdigheter (21). Imidlertid viser det seg ofte å være vanskelig å gjennomføre i klinisk praksis på grunn av utfordringer knyttet til bemanning, utgifter og produksjonskrav (13). Flere studier viser likevel moderat til høy reliabilitet også med kortere opplæring $(15,16)$.

Da vi testet NANTS-no for bruk i klinisk praksis, deltok 46 praksisveiledere og -lærere på et sekstimers kurs med trening i observasjon og vurdering av ikketekniske ferdigheter (14). På slutten av kurset brukte deltakerne vurderingsskjemaet i NANTS-no til å vurdere korte videoscenarioer som demonstrerte ulike grader av ikke-tekniske ferdigheter i en anestesifaglig setting.

Deltakerne vurderte ikke-tekniske ferdigheter med høy reliabilitet (ICC $=0,8)$, nøyaktighet (82 prosent) og generaliserbarhet (G-koeffisient $=0,83)$ (14). Det er imidlertid enklere å vurdere videoscenarioer enn en student i en klinisk setting der man samtidig skal ivareta pasientens behov (22).

\section{Vurdering kan motivere til utvikling}

Vurdering av kompetanse er vesentlig for å stimulere til læring, definere krav og forventninger og sikre at studenter har opparbeidet seg nødvendige ferdigheter. Det viser også ansvarlighet overfor helseforetakene og andre interessenter (23).

Flere kompetansevurderingsverkt $\varnothing \mathrm{y}$ har vist høy reliabilitet ved vurdering av ikke-tekniske ferdigheter under simulering, men få er testet i klinisk praksis (13). NANTS-no har vist høy reliabilitet både i en simuleringsbasert studie (9) og i klinisk praksis (24). 
Vurderingsskalaen i NANTS-no ble benyttet i en kohortstudie for å vurdere utviklingen av tjue anestesisykepleierstudenters ikke-tekniske ferdigheter på tre ulike tidspunkter under utdanningsforløpet (24).

Etter å ha gjennomført et anestesiforløp sammen med en veileder og en lærer skåret hver student seg selv på NANTS-skjemaet, samtidig som veilederen og læreren skåret studenten hver for seg. På forhånd hadde veilederne og lærerne deltatt $i$ et opplæringskurs (14), og studentene hadde fătt undervisning om ikketekniske ferdigheter og trening i bruk av NANTS-no som en del av utdanningen.

\section{«Studentene undervurderte sin egen progresjon.»}

Studentene viste en signifikant utvikling av ikketekniske ferdigheter over tre semestre $(\mathrm{p}<0,001)$. De fikk en gjennomsnittsskår på 3,2 fra veilederne og 2,9 fra lærerne på slutten av det første semesteret og en gjennomsnittsskår på 4,5 fra både veiledere og lærere på slutten av utdanningen. Dette tilsvarer en høy faglig standard (24).

Den høyere gjennomsnittsskåren fra veilederne etter første semester kan ha vært preget av de tette båndene som knyttes mellom veiledere og studenter når de jobber sammen over tid, samt av hvordan veilederne opplever studentene i det daglige arbeidet. Praksislærerne ser ikke studentene like ofte og har ansvaret for flere studenter i helseforetaket, noe som muliggjør en mer objektiv vurdering av studentenes ikke-tekniske ferdigheter.

Et annet interessant funn var at studentene signifikant undervurderte sin egen progresjon $(\mathrm{p}<0,001)$ sammenliknet med vurderingen fra veiledere og lærere (24). Selvvurdering, kritisk refleksjon og formativ tilbakemelding kan alle motivere til utvikling (23), og studentenes undervurdering av egen progresjon kan ha sin årsak i $\varnothing \mathrm{kt}$ innsikt i egne begrensninger (24). 


\section{Kan NANTS-no virke demotiverende?}

En diskusjon ved anvendelse av NANTS-no er om studenter bør vurderes opp mot forventet nivå for en ferdig utdannet anestesisykepleier eller opp mot forventet nivå for hvert semester. Veiledere har uttrykt bekymring for det å skåre studenter lavt i starten fordi ordlyden $\mathrm{i}$ beskrivelsen av de laveste nivåene på vurderingsskalaen vil kunne virke negativ og demotiverende for studentene.

Likevel vil et høyere tall være urealistisk og ikke gi rom for progresjon. Vår erfaring er at studenter aksepterer en lavere skår bedre enn veiledere, og at de ønsker å få en ærlig og reell vurdering av sin faglige progresjon.

\section{Ferdighetene må integreres $\mathbf{i}$ utdanningen}

Tradisjonelt fokuserer sykepleierutdanningene mest på teoretisk kunnskap og utvikling av praktiske/tekniske ferdigheter (6). En strategisk kursendring, der systematisk utvikling av ikke-tekniske ferdigheter implementeres i utdanningen, vil være avhengig av flere faktorer. Først og fremst må det integreres på alle nivåer i utdanningen. Det krever et tettere samarbeid mellom utdanningsinstitusjoner og helseforetak, noe som støttes av rapporten om kvalitet i praksisstudiene fra 2016 (25).

\section{«En systematisk utvikling av ikke-tekniske ferdigheter bør bygge på et validert verktøy.»}

$\AA$ utvikle profesjonell kompetanse forutsetter gunstige læringsforhold - et miljø som er utfordrende, og samtidig trygt - for å kunne stimulere til og tilrettelegge for aktiv fremfor passiv læring (19). I tillegg bør en systematisk utvikling av ikke-tekniske ferdigheter bygge på et validert verktøy som gir et felles språk og rammeverk for observasjon, refleksjon, diskusjon og vurdering (15). 


\section{Studentene motiveres av bevisstgjøring}

Helsetjenesten er avhengig av funksjonsdyktig personell som har de kunnskapene og ferdighetene som kreves for å sikre pasienter en trygg behandling og møte samfunnets krav til kvalitet (24). Systematisk utvikling og vurdering av ikke-tekniske ferdigheter bidrar til en helhetlig kompetanseutvikling som inkluderer mer enn bare tekniske/praktiske ferdigheter $(6,8)$.

Ved å fokusere på og vurdere studenters ikke-tekniske ferdigheter bevisstgjøres de på sine styrker og svakheter. Det kan etter vår erfaring motivere til utvikling hos studentene og sikre en bedre ivaretakelse av pasientene. Det finnes kompetansevurderingsverkt $\varnothing y$ for utvikling og vurdering av ikke-tekniske ferdigheter som kan tilpasses andre utdanninger innenfor sykepleie.

Forfatterne ønsker å takke Ann-Chatrin Linqvist Leonardsen for nyttige innspill.

\section{Referanser}

1. Kohn LT, Corrigan J, Donaldson MS. To err is human: building a safer health system. Washington, D.C.: National Academy Press; 1999.

2. Hjort PF. Uheldige hendelser i helsetjenesten: en lære-, tenke- og faktabok. Oslo: Gyldendal Akademisk; 2007.

3. Jones CPL, Fawker-Corbett J, Groom P, Morton B, Lister C, Mercer SJ. Human factors in preventing complications in anaesthesia: a systematic review. Anaesthesia. 2018;73(S1):12-24.

4. Gundrosen S, Solligård E, Aadahl P. Team competence among nurses in an intensive care unit: the feasibility of in situ simulation and assessing nontechnical skills. Intensive Crit Care Nurs. 2014;30(6):312-7. 
5. Kang E, Massey D, Gillespie BM. Factors that influence the non-technical skills performance of scrub nurses: a prospective study. J Adv Nurs. 2015;71(12):2846-57.

6. Pires S, Monteiro S, Pereira A, Chaló D, Melo E, Rodrigues A. Non-technical skills assessment for prelicensure nursing students: an integrative review. Nurse Educ Today. 2017;58:19-24.

7. Flin R, O'Connor P, Crichton M. Safety at the sharp end: a guide to non-technical skills. Aldershot: Ashgate; 2008.

8. Flin R, Patey R, Glavin R, Maran N. Anaesthetists' non-technical skills. Br J Anaesth. 2010;105(1):38-44.

9. Flynn FM, Sandaker K, Ballangrud R. Aiming for excellence - a simulation-based study on adapting and testing an instrument for developing non-technical skills in Norwegian student nurse anaesthetists. Nurse Educ Pract. 2017;22:37-46.

10. Mykkeltveit I, Bentsen SB. Den norske versjonen av SPLINTS (SPLINTS-no) - et instrument for å utvikle og vurdere ikke tekniske ferdigheter hos operasjonssykepleiere. Nordisk sygeplejeforskning. 2020;10(3):176-84.

11. Endsley MR. Toward a theory of situation awareness in dynamic systems. Hum Factors. 1995;37(1):32-64.

12. Rutherford JS, Flin R, Mitchell L. Teamwork, communication, and anaesthetic assistance in Scotland. British journal of anaesthesia. 2012;109(1):21-6. 
13. Higham H, Greig PR, Rutherford J, Vincent L, Young D, Vincent C. Observer-based tools for nontechnical skills assessment in simulated and real clinical environments in healthcare: a systematic review. BMJ Qual Saf. 2019;28(8):672-86.

14. Flynn FM, Valeberg BT, Tønnessen S, BingJonsson PC. Psychometric testing of a structured assessment instrument for non-technical skills (NANTS-no) for use in clinical supervision of student nurse anaesthetists. J Nurs Meas. 2021;29(1).

15. Fletcher G, Flin R, McGeorge P, Glavin R, Maran N, Patey R. Anaesthetists' Non-Technical Skills (ANTS): evaluation of a behavioural marker system. $\mathrm{Br}$ J Anaesth. 2003;90(5):580-8.

16. Lyk-Jensen HT, Dieckmann P, Konge L, Jepsen RM, Spanager L, Ostergaard D. Using a structured assessment tool to evaluate nontechnical skills of nurse anesthetists. AANA J. 2016;84(2):122-7.

17. Jokelainen M, Turunen $\mathrm{H}$, Tossavainen $\mathrm{K}$, Jamookeeah D, Coco K. A systematic review of mentoring nursing students in clinical placements. J Clin Nurs. 2011;20(19-20):2854-67.

18. Lyth GM. Clinical supervision: a concept analysis. J Adv Nurs. 2000;31(3):722-9.

19. O’Donnell D, Cook N, Black P. Person-centred nursing education. I: McCormack B, McCance T, red. Person-centred practice in nursing and health care: theory and practice. Oxford: John Wiley \& Sons; 2016. s. 99-117.

20. Sirevåg I, Aamodt KH, Mykkeltveit I, Bentsen SB. Student supervision using the Scrub Practitioners' List of Intraoperative Non-Technical Skills (SPLINTS-no): a qualitative study. Nurse Educ Today. 2021;97:104686. 
21. Hull L, Arora S, Symons NR, Jalil R, Darzi A, Vincent C, et al. Training faculty in nontechnical skill assessment: national guidelines on program requirements. Ann Surg. 2013;258(2):370-5.

22. Flin R, Maran N. Basic concepts for crew resource management and non-technical skills. Best Pract Res Clin Anaesthesiol. 2015;29(1):27-39.

23. Wong A. Review article: teaching, learning, and the pursuit of excellence in anesthesia education. Can J Anaesth. 2012;59(2):171-81.

24. Flynn FM, Bing-Jonsson PC, Tønnessen S, Valeberg BT. Educating for excellence: a cohort study on assessing student nurse anesthetists' non-technical skills in clinical practice. AANA J (under publisering). 2021.

25. Universitets- og høgskolerådet. Kvalitet i praksisstudiene i helse- og sosialfaglig høyere utdanning. 2016. 